\title{
Shallow crustal earthquake models, damage, and loss predictions in Banda Aceh, Indonesia
}

\author{
Ibnu Rusydy ${ }^{1,2^{*}}$ (D, Y Yunita Idris ${ }^{2,3}$, Mulkal $^{4}$, Umar Muksin ${ }^{2,5}$, Phil Cummins ${ }^{6}$, Muhammad Nouval Akram² \\ and Syamsidik ${ }^{2,3}$
}

\begin{abstract}
The city of Banda Aceh stands on Holocene fluvial basin sediment, surrounded by the Aceh and Seulimeum fault segments where large magnitude earthquakes can occur at any time. Such earthquakes could cause extensive physical infrastructure damages, injuries, and economic loss. This research aims to produce several earthquake scenarios, to determine the damage ratio of the buildings and its distribution in these different scenarios and to estimate the number of potential casualties and economic loss. Data analysis in this research includes modelling an earthquake by applying a ground motion model for shallow crustal earthquakes to yield an intensity map after the correction for site effects. The damage ratios for different types of buildings were calculated using the fragility curves of buildings that were developed by other researchers. Building occupants at different times, building damage ratios, and injury ratios were used to determine the number of injured residents in the earthquake scenario. The results show that Banda Aceh could be potentially experience earthquake ground motion within the intensity range from MMI VII to IX due to earthquakes of Mw 6.5 to Mw 7.0. The Mw 7.0 earthquake on the Aceh segment is the worst case scenario, causing building damage throughout Banda Aceh with casualty rates of 3.5$20 \%$ of the population in buildings in general if it happened during daytime, with economic loss about 3320 million USD. Mitigation and preparedness programs for the Banda Aceh community are therefore very important in order to reduce the potential level of damage, personal injury, and economic loss due to future earthquakes.
\end{abstract}

Keywords: Earthquake, Damage prediction, Loss prediction, Banda Aceh city

\section{Introduction}

The ability to reliably estimate earthquake damage is critical in evaluating building fragility, and forecasting damage and casualties due to a potential earthquake that could happen at any time and at any magnitude. Related to this, the vulnerability assessment of urban centres has been introduced by Baiocchi et al. (2012), which includes the vulnerability assessment of public infrastructure, private investment, and residential construction. The investigation of the building vulnerability, whether public infrastructure or residential construction, should also

\footnotetext{
* Correspondence: ibnu@unsyiah.ac.id

${ }^{1}$ Department of Geological Engineering, Faculty of Engineering, Syiah Kuala University, Banda Aceh, Indonesia

${ }^{2}$ Tsunami and Disaster Mitigation Research Center (TDMRC), Syiah Kuala

University, Banda Aceh, Indonesia

Full list of author information is available at the end of the article
}

consider the mapping of the groundwater and high pore pressure sediment below the surface for the possibility of the sediment liquefaction and potential site amplification (Wood and Steedman 1992).

Assessment of vulnerability with respect to seismic activity for Indonesian cities like Banda Aceh is a concern not only because Indonesia lies on the ring of fire where seismic activity is high, but also because Banda Aceh stands on Holocene fluvial basin sediment and is surrounded by the Aceh and Seulimeum fault segments. The Aceh and Seulimum fault segments are part of the Great Sumatra fault (GSF). According to Ito et al. (2012), the northern part of the GSF contains a $200 \mathrm{~km}$ long segment that shows no seismic activity in at least 170 years. However, the northern portion of this fault segment, aseismic creep occurs from a $7.3 \pm 4.8 \mathrm{~km}$ depth at the rate of $2.0 \pm 0.6 \mathrm{~cm} /$ year. In the southwest 
part of the segment, Ito et al. (2012) estimated a locking depth of $14.8 \pm 3.4 \mathrm{~km}$, with a down-dip slip of $1.6 \pm 0.6$ $\mathrm{cm} /$ year. Those segments of the faults are capable of producing a Mw 7.0 earthquake that could put Banda Aceh in the high risk zone. Hence, the study of the site characteristics, which involves the generation of a seismic hazard map, and simulating earthquake loss prediction, are crucial for Banda Aceh. The Earthquake loss prediction is a method used to estimated damages, including infrastructure, human injuries, and economic loss under different earthquake scenarios (ground shaking and liquefaction) as well as the types of building which cause human casualties (Miura et al. 2008; Hashemi and Alesheikh 2011; Karimzadeh et al. 2014; Rusydy et al. 2017a; Guettiche et al. 2017; Saputra et al. 2017; Karimzadeh et al. 2017; Rusydy et al. 2018a; Rusydy et al. 2018b; Liu et al. 2019).

This paper aims to estimate the distribution and ratio of building damage as the results of several earthquake scenarios with different intensities, magnitudes and accounting for site amplification, and liquefaction effects. This paper also aims to predict the casualty numbers and economic loss in each earthquake scenario. In this study, the modelling of the ground shaking intensity resulting from different earthquakes scenarios were generated, building vulnerability depend on the fragility curve and liquefaction effect was computed, and the number of casualties in Banda Aceh estimated. The times of occurrence of earthquakes modelled in this research were $2 \mathrm{AM}$ for night-time and $2 \mathrm{PM}$ for day-time scenarios. The result of this study will contribute to enhancing earthquake disaster mitigation in the city. This paper will also highlight the parts of Banda Aceh that could suffer the most damage and economic loss due to ground shaking and associated liquefaction from potential future earthquakes.

\section{Tectonics and seismicity of the study area}

The great Aceh-Andaman Mw 9.1 earthquake of December 26, 2004 and the associated tragedy in Aceh province brought the active tectonics of this area into global focus (McCaffrey 2009). In the western part of Sumatra, a subduction zone is present between the Indo-Australian Plate and the Eurasian Plate. The IndoAustralian plate moves northward and is subducted beneath the Eurasia plate at approximately $5 \mathrm{~cm} /$ year (McCaffrey 2009). The oblique convergence system between the Indo-Australia plates and the Eurasian plate establish the Great Sumatra Fault (GSF), a major rightlateral trench fault system $1900 \mathrm{~km}$ in length (McCaffrey 2009; Sieh and Natawidjaja 2000).

The GSF completely traverses Sumatra Island, controlling much of the island's tectonics and has great potential to produce a large magnitude earthquakes (Sieh and
Natawidjaja 2000; Chlieh et al. 2008; Muksin et al. 2018). Sieh and Natawidjaja (2000) divided the GSF into 19 major segments. In details, the 17 segments of the GSF are less than $200 \mathrm{~km}$ in length, with the other 2 being greater than $200 \mathrm{~km}$. The two longest segments are the Aceh segment $(200 \mathrm{~km})$ and Renun segment $(220 \mathrm{~km})$.

Furthermore, Sieh and Natawidjaja (2000) defined the GSF in Aceh province as four major segments including: the Tripa segment (180 km-long), Aceh segment (200 $\mathrm{km}$-long), Seulimeum segment (120 km-long) and Batee segment (150 km-long). The Aceh and Seulimeum segments are the closest segments to Banda Aceh. The Seulimeum segment experienced a magnitude M 7.2 earthquake in 1936 (Muksin et al. 2018). In 1965 another M 6.5 earthquake destroyed Krueng Raya, which is located closer to the Seulimeum segment (Sieh and Natawidjaja 2000). There were no major events recorded in the last 170 years on the Aceh segment. This earthquake history with few events in recent years suggests the potential for a large seismic event to happen in this region in the future. Ito et al. (2012) estimated that the Aceh segment could produce a Mw 7 earthquake, and endanger more than 260,000 residents of Banda Aceh.

Banda Aceh is bounded to the south-west by the Aceh segment and to the northeast by the Seulimeum segment, as shown in Fig. 1. From the west of coastal range moving south, the surface geology bounding the Aceh segment consists of pre-tertiary limestone. According to Barber and Crow (2005), this limestone formed in late Jurassic to early Cretaceous from a portion of Gondwanaland. Volcanic foothills, of Pleistocene to Holocene ages, are located on the northern coast of both sides of the Seulimeum segment. The alluvial deposit closest to the coastal area of Banda Aceh extends to a depth of more than $200 \mathrm{~m}$ and becomes thinner upstream (Bennet et al. 1981).

Banda Aceh is located on the Krueng Aceh basin, which was formed in response to fluvial processes. According to Bennet et al. (1981), the area below Banda Aceh city was formed during the Pleistocene and Holocene from undifferentiated alluvium and coastal sediments which consist of gravels, sands, and muds. Culshaw et al. (1979) noted that ancient sand-bars run sub-parallel to the coastline of Banda Aceh city. These sand-bars consist of brown to grey moderately weathered fine to medium sized grains with some silty sands. The lithology of the sand-bars are very similar to new beach sand. Having sand-bar formations along with Holocene sediments makes Banda Aceh a likely liquefaction-prone zone; furthermore, it will amplify the ground shaking of the earthquake. Banda Aceh city covers 9 sub-districts and 90 villages having different areas and populations; according to local authorities, 261,034 people live in Banda Aceh city as of September 2017. 


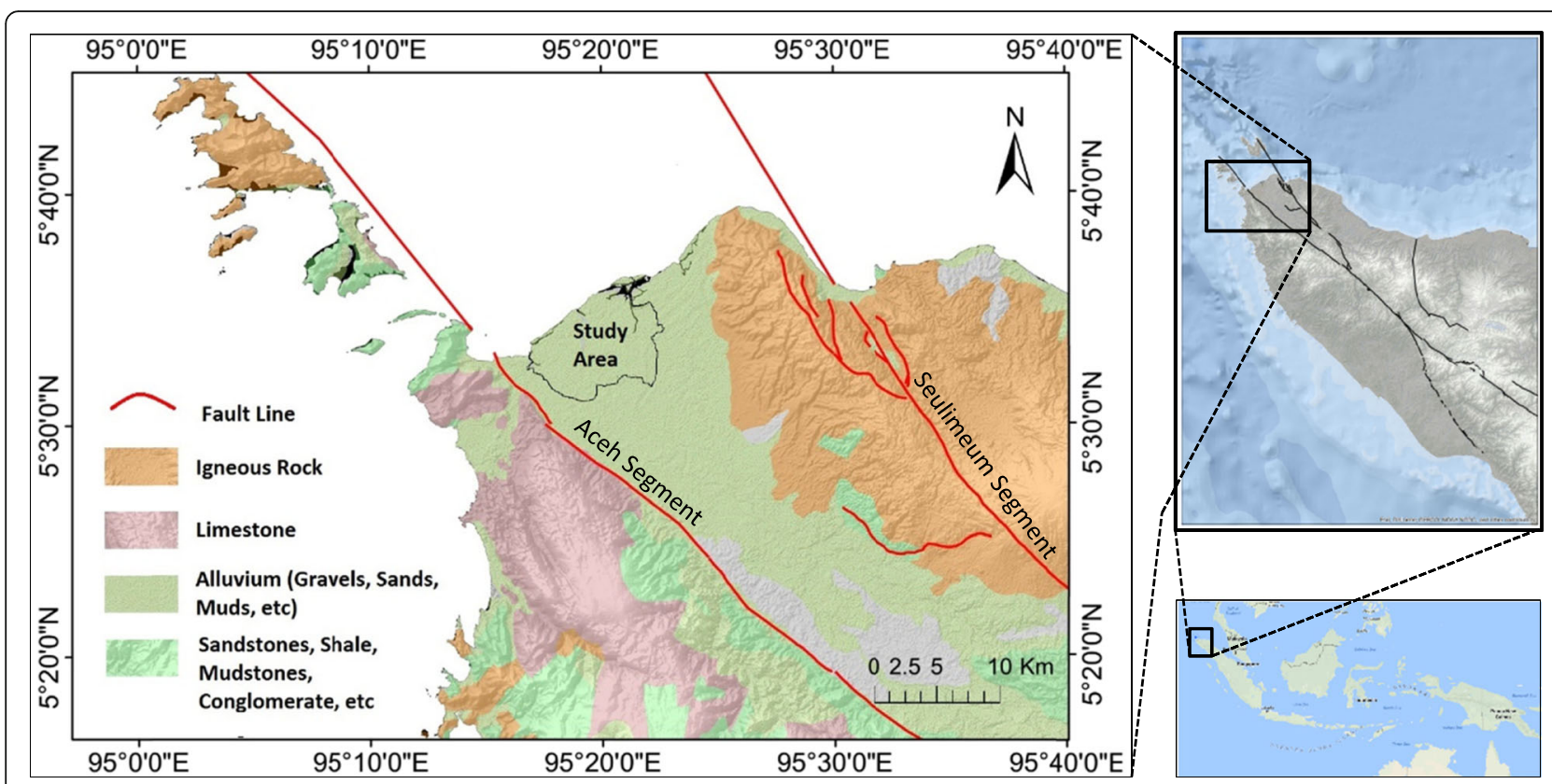

Fig. 1 The tectonic setting of northern Sumatra Aceh Province and geological map of Study area (Bennet et al. 1981)

\section{Methodology}

The tectonic and geological data obtained from Bennet et al. (1981), Sieh and Natawidjaja (2000) were digitized using ArcGIS software and overlaid with a SRTM map from NASA. First, the active fault location and magnitude estimation had to be determined from earlier studies prior to developing earthquake scenarios. The earthquake model applied to the various scenarios was well documented and based on previous studies of local and regional tectonics from Bennet et al. (1981), Sieh and Natawidjaja (2000), and Ito et al. (2012). The ground shaking map was developed using Intensity Prediction Equations (IPEs) as designed by Allen et al. (2012). After site coefficient correction, the IPEs equation was used to produce an intensity map at the levels of the bedrock and surface. Damage estimates of several types of buildings were determined using building fragility curves. As there were no published building fragility curves specific to Indonesia, this study used fragility curves developed for the Philippines by Tingatinga et al. (2013) and Naguit et al. (2017). Using the Philippines's fragility curve was appropriate because the building construction types in Indonesia are quite similar to those of the Philippines. The detailed methodology including data preparation, earthquake scenario development, building damage assessment analysis, casualty and economy loss estimation, are shown in Fig. 2.

\section{Data preparation}

GIS analysis for earthquake damage prediction requires shape-file data to be input into the GIS software. The tectonic and geological data were obtained from Bennet et al. (1981), Sieh and Natawidjaja (2000), and Barber and Crow (2005). The 2011 Banda Aceh building data were received from the Development Plan Department of Banda Aceh city. The 2016 Banda Aceh city building data using the GIS tool were then updated and digitized.

\section{Earthquake scenario}

The understanding of seismology has developed significantly over the past decades, especially the study and modelling of earthquake-generated ground motion. Empirical ground motion models have been developed that, give an earthquake's magnitude and distance, provide numerical estimates of ground motion intensity, in terms of both physical indicators like Peak Ground Acceleration (PGA), as well as macroseismic intensities, or Modified Mercalli Intensity (MMI) (Rusydy et al. 2017a; Rusydy et al. 2018a; Rusydy et al. 2018b). The latter are referred to as IPEs (Intensity Prediction Equations), and are particularly useful for rapidly and simply communicating earthquake hazard and risk to the media and public (Allen et al. 2012; Rusydy et al. 2017a; Rusydy et al. 2018a).

Different tectonic settings have different applicable ground motion models, but the IPEs developed by Allen et al. (2012) were specifically designed for a wide range of tectonic environments. Also, the Allen et al. (2012) IPEs were designed to be applicable for distance, depth and magnitude ranges that match well the earthquake scenarios of our study: distance $2.5-15 \mathrm{~km}$, depth $<20$ $\mathrm{km}$, and $5.0<\mathrm{Mw}<7.9$. For these reasons we chose the 


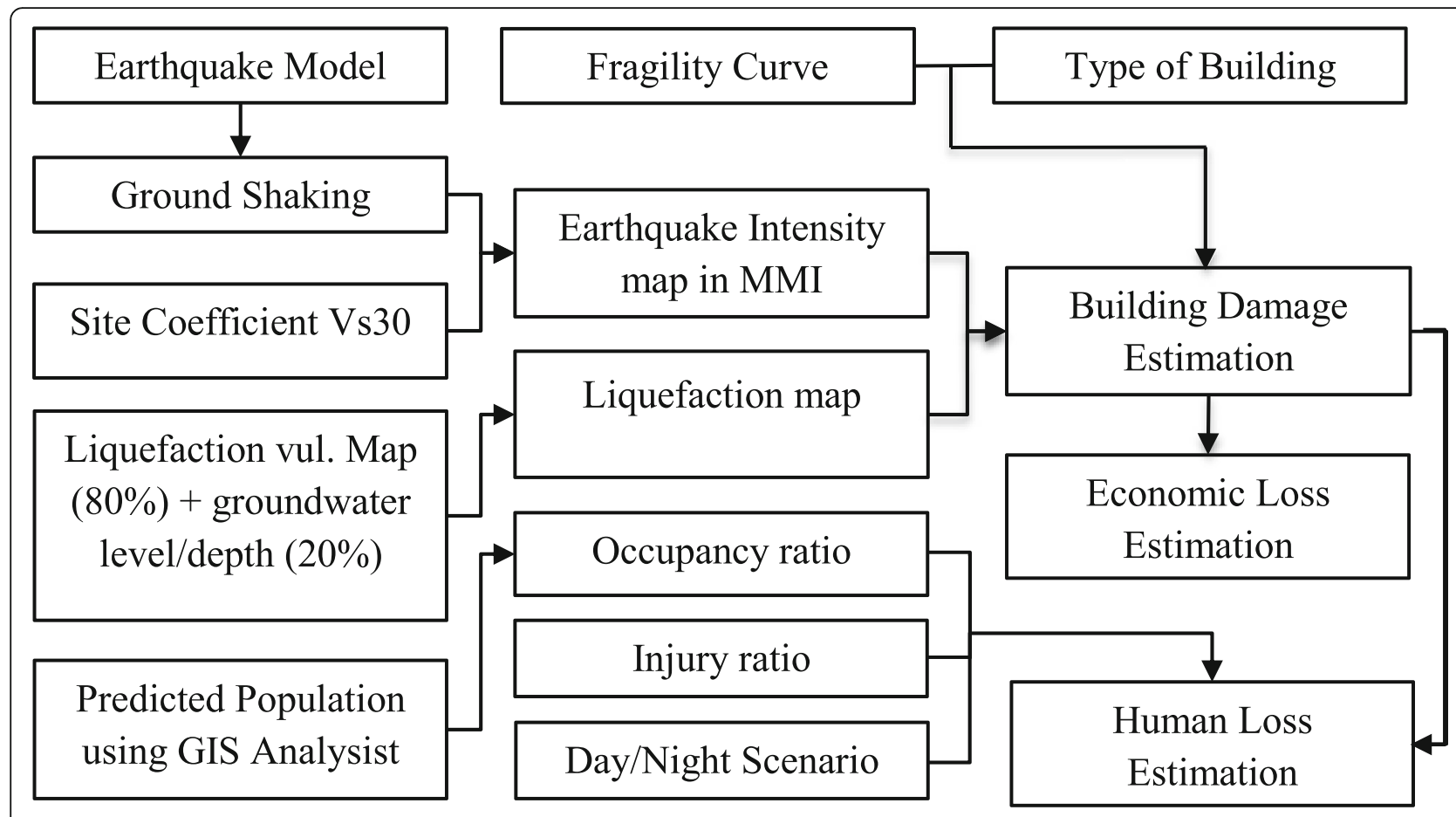

Fig. 2 The Flowchart of Earthquake Lose Prediction in Several Earthquake Scenarios

Allen et al. (2012) IPEs as the most suitable for our study. These IPEs were generated using 13,077 earthquakes data around the world since 1973; 1613 of the earthquakes are from Asia. The IPEs (Eq. 1) were used to estimate the intensity of the earthquake at each distance to the rupture zone and Eq. (2) was proposed by Borcherdt (1997) and Cinicioglu et al. (2007) to compute the site amplification effect and it's utility as applied to shallow crustal earthquakes in Banda Aceh city:

$$
\begin{aligned}
& I\left(M, R_{r u p}\right)=c_{0}+c_{1} M+c_{2} \ln \sqrt{R_{r u p}^{2}+\left[1+c_{3} e^{(M-5)}\right]^{2}}+S \\
& S=3.48 \log (F v)
\end{aligned}
$$

Where $I$ stands for the intensity (MMI), $M$ is the earthquake magnitude (Mw), $R_{\text {rup }}$ is the closest distance to the rupture zone $(\mathrm{km}), c_{0}, c_{1}, c_{2}$ and $c_{3}$ are coefficients with the values $3.950,0.913,-1.107$, and 0.813 , respectively, and $S$ is the site correction where $F$ represents the amplification capacity of the local soil ( $F v$ for long periods, $F a$ for short periods).

\section{Site coefficient and liquefaction effect}

The site coefficient for Banda Aceh city was determined using shear-wave velocity travel-time averaged over a depth of 30-m (Vs30) data from Muzli et al. (2014) and Jamaluddin et al. (2018) in order to calculate the amplification factor. Muzli et al. (2014) and Jamaluddin et al. (2018) determined Vs30 using the MASW (Multichannel
Analysis of Surface Wave) method from 53 locations, which were placed approximately $1 \mathrm{~km}$ apart. The result showed that the Banda Aceh area has stiff and soft soil layers. To determine the amplification factor from the Vs30 data, this study used Eq. (3) from Borcherdt and Eeri (1994) to consider how a mid-short period amplification of earthquake ground motion could affect Banda Aceh:

$$
F v=\left[\frac{1050}{V s}\right]^{m v}
$$

Where $F v$ is the mid-short period of the amplification factor, 1050 is the shear wave velocity in firm to hard rock and $m w$ is the value for the peak ground acceleration (PGA). According to the Tim Revisi Peta Gempa Indonesia (2010), the PGA value for $10 \%$ exceedance in 50 years in Banda Aceh is $0.4 \mathrm{~g}$, and is dominated by the GSF. According to a prior study of Borcherdt and Eeri (1994), the $m w$ value at $0.4 \mathrm{~g}$ is 0.45 .

Liquefaction is one of the side effects of the seismic ground motion that can damage buildings and infrastructure. Several factors influence liquefaction following an earthquake, including magnitude, intensity and the water table level (Holzer et al. 2011). The water table levels of the groundwater in Banda Aceh city were determined using a 1D Geo-electrical method in this research. This method was applied to 20 locations and combined with the liquefaction vulnerability map of 
Banda Aceh City that was developed by Tohari et al. (2015) as shown in Fig. 3. The water table map and liquefaction vulnerability map were then utilised to produce the new liquefaction map. Groundwater depth is a critical parameter in studying the liquefaction potential zone (Chung and Rogers 2013), and the effect of varying the depth of groundwater influenced liquefaction by $20 \%$ (Tonkin and Taylor Ltd 2013). The detailed weights used in the GIS analysis in this study are shown in the flowchart (see Fig. 2).

\section{Earthquake loss prediction analysis}

Banda Aceh city lies $2.5 \mathrm{~km}$ far from the Aceh segment and $15 \mathrm{~km}$ from the Seulimeum segment. Earthquakes occurring on these faults are only a short distance from the city, and given that these are shallow crustal earthquakes large events are likely to result in high levels of building damage and casualties among residents (Allen et al. 2012). Different building typologies have different resistances to ground shaking, which also varies from one area to another and can be estimated from the fragility curves developed by Tingatinga et al. (2013) and Naguit et al. (2017). The types of building studied by them were similar to the typical buildings proposed by FEMA (2010) and were similar to the construction types in Aceh Province - see research conducted by Gentile et al. (2019) and Idris et al. (2019). The fragility curve indicated the damage ratio of the building on a scale of 0 to 1 as a function of ground shaking/intensity in MMI, with the value 1 corresponding to $100 \%$ damage.

The data of 79,421 buildings in Banda Aceh city were inventoried and divided into three typologies; (1) LowRise Concrete Moment Frame (C1-L), 78,006 buildings; (2) Low-Rise Light Wood Frame (W1-L), 802 buildings; (3) Medium Rise Concrete Moment Frame (C1-M), 612 buildings. The distribution of the types of buildings in Banda Aceh city is shown in Fig. 4a. To calculate the damage ratio for the different construction types, the fragility curves in Fig. 4b were used, which express damage ratio in terms of the intensity experienced by each building. C1-L and C1-M buildings have nearly similar trend of fragility curves, but the W1-L curve has lower damage ratios. The lighter wood material makes the W1-L building more resistant to the earthquake ground motion compared to $\mathrm{C} 1-\mathrm{L}$ and $\mathrm{C} 1-\mathrm{M}$, as has been shown by field study conducted by Naguit et al. (2017).

The damage ratio associated with each building yields varying numbers of casualties among people trapped in a collapsed or heavily damaged building (Hashemi and Alesheikh 2011; Rusydy et al. 2017a; Rusydy et al. 2018a). Building collapse, the primary cause of human injury in earthquakes, results in a fatality rate of $75 \%$ (Coburn and Spence 2002). The casualty rate for each building is more difficult to estimate as it differs from one earthquake to another, and the existing data on casualty rates yields an inadequately wide range of numbers of people injured. The number of injuries depends on

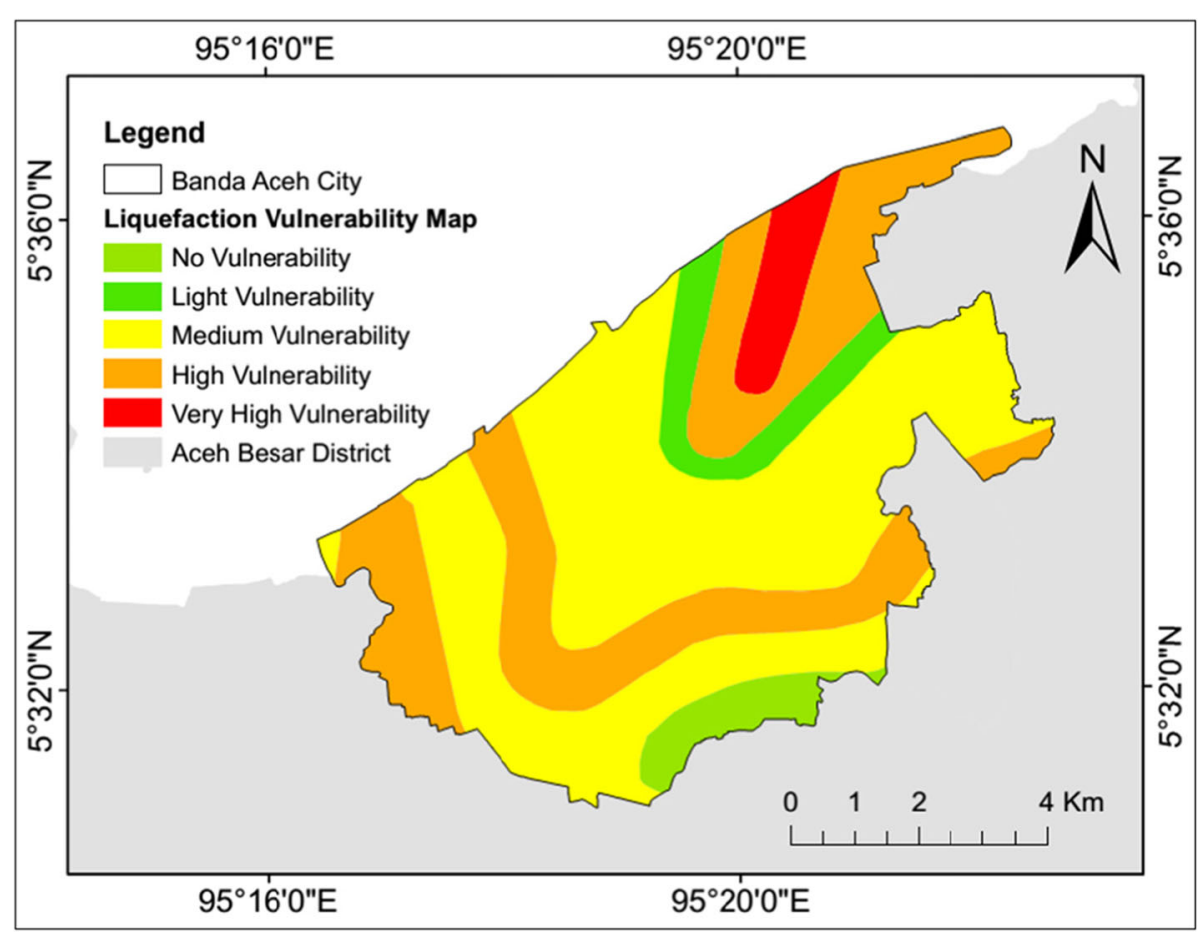

Fig. 3 Liquefaction Vulnerability Map of Banda Aceh City Proposed by Tohari et al. (2015) 

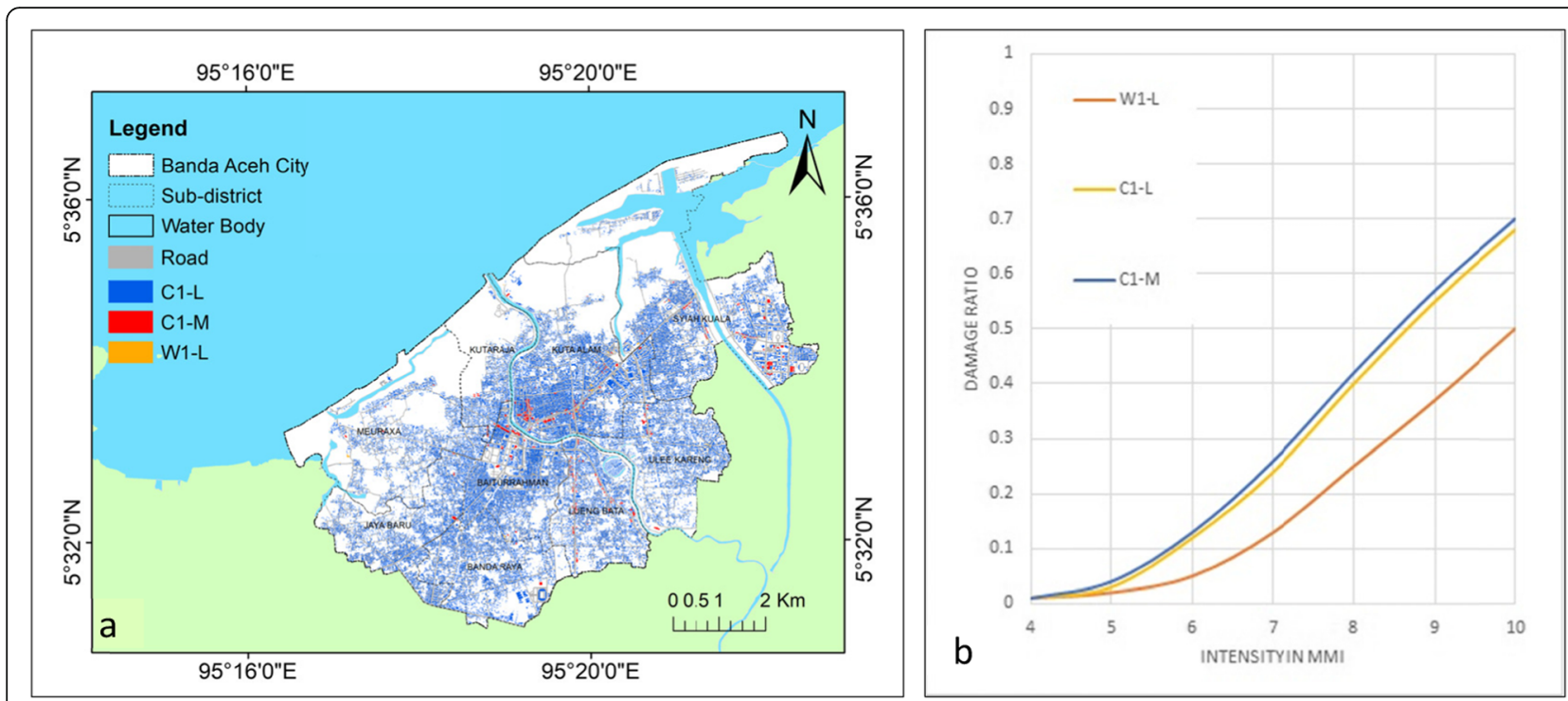

Fig. 4 a The building typology distribution in Banda Aceh city measured in 2016. b Heuristic fragility curve of 3 variants of buildings in Banda Aceh (Tingatinga et al. 2013; Naguit et al. 2017)

each building's population. It is difficult to record the population for each building to solve this equation; therefore, this study calculated the predicted population data of Banda Aceh city and the total area of all houses in Banda Aceh city. This calculation is applicable only to residential buildings. The equations of house population are shown in Eqs. (4) and (5). This paper used the Eq. (5) that developed by Hashemi and Alesheikh (2011) to estimate the number of injuries. The number of injured in that equation was based on the occupancy at the time of the earthquake, damage ratio, population of each building, and injury ratio. The worst case scenario for the injury ratio is as shown in Table 1 . Table 2 shows the population distribution in all sub-districts in Banda Aceh based on the 2017 population census.

Population $=\frac{\text { Population in one village according to statistic data }}{\text { Total Area of The Houses in one village }} \times$ Area of House

Injury $=$ Occupancy ratio $x$ population $x$ damage ratio $x$ injury ratio

Based on building damage ratio models, this study was able to estimate the economic loss for each buildings as

Table 1 Injury ratio for worst-case damage scenario in different type of building according to Hashemi and Alesheikh (2011)

\begin{tabular}{lll}
\hline No. & Type of buildings & Injury ratio \\
\hline 1. & RC Building $<4$ stories (C1-L) & 0.2 \\
2. & RC Building $>4$ stories (C1-M) & 0 \\
3. & Timber Frame Building (W1-L) & 0.4 \\
\hline
\end{tabular}

well as each sub-district. The economic loss estimation model are an important information for decision makers and policy makers (Guettiche et al. 2017). Financial loss estimation study due to earthquake event, has been introduce by Sun et al. (2012); Jaiswal and Wald (2013); Guettiche et al. (2017). This study, applying the Eq. (6) to estimate the economic loss each sub-districts in Banda Aceh city.

Economic Loss $=$ damage ratio $\times$ building area $x$ stories $\times$ price of building

The damage ratio of a building was derived from the model of damage for different earthquake scenarios on the Aceh and Seulimeum segments. The building information that have been collected previously by GIS analysis and building inventory, include area and number of

Table 2 The population of Banda Aceh city for each sub district according to the local authority

\begin{tabular}{llll}
\hline No. & Sub-districts & Populations & The number of villages \\
\hline 1. & Baiturrahman & 34,721 & 10 \\
2. & Kuta alam & 46,766 & 11 \\
3. & Meuraxa & 23,169 & 16 \\
4. & Syiah Kuala & 36,070 & 10 \\
5. & Lueng bata & 26,172 & 9 \\
6. & Kuta raja & 14,388 & 6 \\
7. & Banda Raya & 25,492 & 10 \\
8. & Jaya Baru & 27,316 & 9 \\
9. & Ulee kareung & 26,940 & 9 \\
\hline
\end{tabular}


building stories. The price of buildings was based on the standard price of buildings in Banda Aceh established by the Major of the city each year. It refer to the Banda Aceh mayor's decision number 476 about the standard construction price for the construction of state buildings in the city of Banda Aceh city in 2017. The standard price of buildings in IDR (Indonesia Rupiah) and USD (United States Dollar) at Banda Aceh was divided among 5 different types of buildings and depends on the different type of occupancy and type of construction provided in Table 3. Public buildings, including schools and governmental offices, are typical of building type B, while special public buildings such as hospitals, laboratories, and hotels were referred as building type A. One and three storeys reinforced concrete houses (C1-L) were referred as houses type $\mathrm{B}$, while timber construction houses were referred to as houses of type $\mathrm{C}$.

\section{Results and discussion} Validation of the models

The accuracy of the earthquake intensity and damage prediction models is of concern. As a first step, the models of IPEs (Intensity Prediction Equations) and building damage for each building typology should be validated. Such a validation was performed for previous recorded earthquakes in the region. Earthquake models are very sensitive to magnitude and shaking attenuation. The damage models rely on the fragility curve, and the injury model depends on the injury ratio. Indonesia has numerous large magnitude shallow crustal earthquakes. The IPEs equation proposed by Allen et al. (2012) was used in this study to develop the earthquake models. The IPEs was validated by a review of recorded historical shallow crustal earthquakes in Aceh province. The most memorable and well documented shallow, crustal earthquake in Aceh province was the Tanoh Gayo earthquake, which occurred on July 2, 2013 with magnitude Mw 6.1, at a depth of $10 \mathrm{~km}$ (Rusydy et al. 2015).

The Tanoh Gayo earthquake was determined to be a shallow crustal earthquake. Rusydy et al. (2015) and Daryono and Tohari (2016) noted that this earthquake source had not been recognized as part of the GSF. The earthquake source belonged to another segment of faults

Table 3 The price of buildings per area in Banda Aceh city according to Mayor's decision of Banda Aceh city

\begin{tabular}{llll}
\hline No. & Type of buildings & \multicolumn{2}{c}{ Standard price per area } \\
\cline { 3 - 4 } & & IDR & USD \\
\hline 1 & Building A (Special Public Buildings) & $6,080,000$ & 433 \\
2 & Building B (Public Buildings) & $4,770,000$ & 340 \\
3 & Houses type A & $5,870,000$ & 418 \\
4 & Houses type B & $5,850,000$ & 416 \\
5 & Houses type C & $4,420,000$ & 314 \\
\hline
\end{tabular}

that had not been recognized in the earthquake map previously. Using macro seismic surveys and surface ruptures, Rusydy et al. (2015) and Daryono and Tohari (2016) found the segment is part of a previously unknown fault that crosses Takengon City striking to the north-west. Based on their findings, this study used the rupture zone as the source of the Tanoh Gayo earthquake as shown in Fig. 5. The Vs30 used to estimate the amplification factor for the Aceh Tengah and Bener Meriah districts, which were affected by the Tanoh Gayo earthquake, was determined by Rusydy et al. (2017b) using multichannel analysis of surface waves (MASW) measurements. The actual intensity of the 2013 Tanoh Gayo earthquake was derived from Rusydy et al. (2015) in a survey performed a few days after the Tanoh Gayo earthquake.

The intensity validations showed some differences between the IPEs and the actual intensity (see Table 4). For the Timang Gajah area, the actual intensity was in the range of 7-9 but the IPEs appear model the maximum intensity in this range. For other areas, the IPEs values are shown to be higher than the actual intensity. Overall, the IPEs intensity are overestimates by about 0.1-0.5 MMI. These overestimates could be due to the IPEs effectively assuming uniform slip over the rupture area. In fact, each rupture involves along-strike variations in slip which results in different spatial distributions of intensity. On other hand, the local geology can also cause dissimilar amplification values; accordingly, it varies from one site to others and it depends on local soil classifications as studied previously by Karimzadeh et al. (2017).

The damage model validation was conducted using a visual assessment method. A few days after the 2013 Tanoh Gayo earthquake, photographs of damaged buildings at selected validation points were taken. Those photos were used to determine the damage ratio. Hence, the visual classification of damage ratio referred to the work of Okada and Takai (2000). The result of the validation process is shown in Table 5 .

In Timang Gajah subdistrict, the Low-Rise Concrete Moment Frame (C1-L) buildings experienced moderate (0.2) to heavy damage (0.6), as did those in Bebesan and Silih Nara due to the Tanoh Gayo earthquake. In the Ketol subdistrict, C1-L buildings experienced heavy damage (0.4-0.6). Accordingly, the damage model for C1-L buildings produced estimates for damage in the Tanoh Gayo earthquake that are in the range of the actual damage. Low-Rise Light Wood-Frame (W1-L) buildings suffered moderate $(0.1-0.2)$ to heavy damage (0.4-0.6) in Timang Gajah and Ketol but none to moderate actual damage in Silih Nara. The actual damage of W1-L buildings was similar to the model in Timang Gajah, but overestimated in Ketol. 


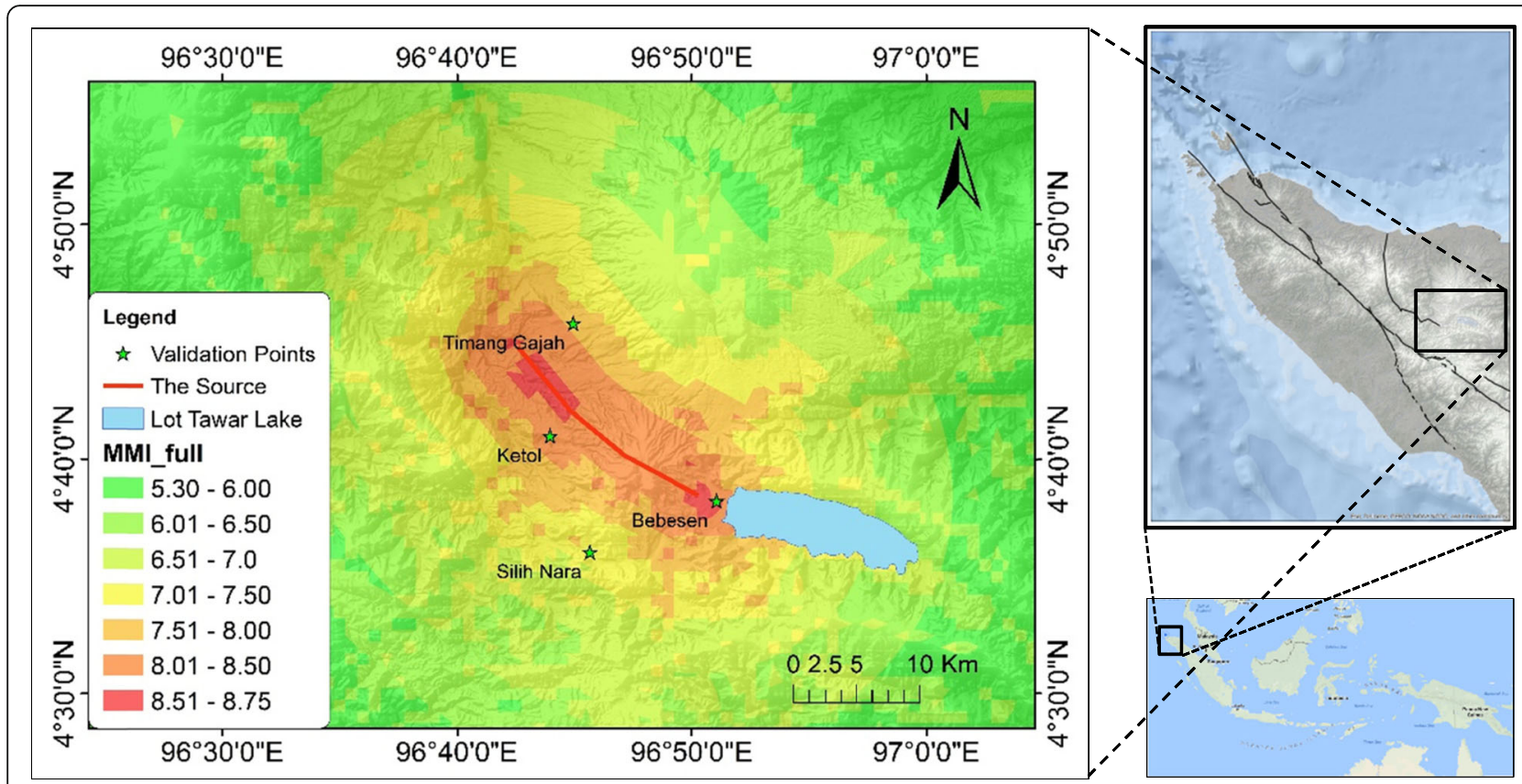

Fig. 5 Rupture zone for the Tanoh Gayo earthquake 2013 and intensity map produced using the IPEs and the location of validation points. The rupture zone is set according to Rusydy et al. (2015) and Daryono and Tohari (2016). Digital elevation model derived from NASA 2007

\section{Earthquake intensity models}

The earthquake intensity model was based on an IPEs designed for global applications (see Eq. (1)). This equation was used to predict the intensity of the earthquake in the bedrock and at the surface. The effect of site amplification on the surface intensity are calculated using Eq. (2) with appropriate site coefficient. At large scale (see Fig. 6), the Vs30 data for calculating the site coefficient using Eq. 3 was taken from the global Vs30 model developed by Allen and Wald (2009), yet for small scale (see Fig. 7a), the Vs30 data were derived from Muzli et al. (2014) and Jamaluddin et al. (2018). These data then were applied in GIS analysis to produce the earthquake scenario ground motions shown in Fig. 6. Earthquake scenarios correspond to Mw 7 and Mw 6.5 earthquakes for each of the Aceh and Seulimeum fault segments. A previous study noted that the highest potential magnitude earthquake that could be produced in the Aceh segment is in the range Mw 6.5-7.0 (Ito et al. 2012). The 1964 earthquake at the Seulimeum segment had a magnitude of 6.5 (Sieh and Natawidjaja 2000) and the maximum magnitude event could be Mw 7. The models showed that the degree of intensity at a particular point depends on the distance from the earthquake and the local site coefficient. The USGS value of Vs30 used to calculate the site coefficient is very suitable for regional earthquake models, but is less applicable to local earthquake models. To determine the details of spatial variation of the earthquake scenario intensities in Banda Aceh itself, this study used values of Vs30 taken form the MASW studies of Muzli et al. (2014) and Jamaluddin et al. (2018).

\section{Site coefficient analysis}

Detailed Vs30 studies in Banda Aceh city were conducted by Muzli et al. (2014) and Jamaluddin et al. (2018), and these data were used here to calculate the site coefficient and amplification factors. The locations of the Vs30 data and the interpolated results are shown in Fig. 7a. Based on these results, this study calculated the amplification factor for Banda Aceh. Those results are illustrated in Fig. $7 \mathrm{~b}$. The amplification factor $(F v)$

Table 4 The earthquake intensity comparison between the IPEs model and actual intensity from Rusydy et al. (2015)

\begin{tabular}{lllllll}
\hline Sub-district & $\begin{array}{l}\text { Distance to } \\
\text { rupture (R }\end{array}$ & $\begin{array}{l}\text { Intensity at } \\
\text { bedrock (IPEs) }\end{array}$ & Amplif. (Fv) (Rusydy et al. 2017b) & S & $\begin{array}{l}\text { Intensity at surface } \\
\text { in MMl (IPEs) }\end{array}$ & $\begin{array}{l}\text { Actual intensity } \\
\text { at surface }\end{array}$ \\
\hline Timang Gajah & $4.5 \mathrm{~km}$ & 7.5 & 2.7 & 1.5 & 9.0 & $7-9$ \\
Ketol & $2.5 \mathrm{~km}$ & 7.9 & 2.7 & 1.5 & 9.4 & $8-9$ \\
Bebesen & $1.5 \mathrm{~km}$ & 8.1 & 2.0 & 1.0 & 9.1 & $7-9$ \\
Silih Nara & $8.0 \mathrm{~km}$ & 7.1 & 1.3 & 0.4 & 7.5 & $6-7$ \\
\hline
\end{tabular}


Table 5 The damage comparison between our damage model and actual damage from the 2013 Tanoh Gayo earthquake

\begin{tabular}{|c|c|c|c|c|c|c|}
\hline \multirow[t]{3}{*}{ Sub-district } & \multirow{3}{*}{$\begin{array}{l}\text { Intensity at } \\
\text { surface in MMI (IPEs) }\end{array}$} & \multirow{3}{*}{$\begin{array}{l}\text { Actual intensity } \\
\text { at surface MMI }\end{array}$} & \multicolumn{4}{|c|}{ Damage ratio } \\
\hline & & & \multicolumn{2}{|c|}{ Our damage model } & \multicolumn{2}{|c|}{ Actual damage } \\
\hline & & & C1-L & W1-L & $\mathrm{C1-L}$ & W1-L \\
\hline Timang Gajah & 9.0 & $7-9$ & 0.55 & 0.37 & $0.2-0.6$ & $0.4-0.6$ \\
\hline Ketol & 9.4 & $8-9$ & 0.59 & 0.42 & $0.4-0.6$ & $0.2-0.4$ \\
\hline Bebesen & 9.1 & $7-9$ & 0.56 & 0.38 & $0.2-0.6$ & - \\
\hline Silih Nara & 7.5 & $6-7$ & 0.32 & 0.19 & $0.2-0.4$ & $0.0-0.2$ \\
\hline
\end{tabular}

was substituted into Eq. (2) to compute the site coefficient $(S)$. The results of the site coefficient data used in developing the earthquake intensity models associated with the nearest fault system to Banda Aceh are shown in Fig. 7c, d, e, f. Soft soils (low Vs30) trigger a higher amplification factor, and stiff soils (high Vs30) yield a lower amplification factor (Rusydy et al. 2017b).

The highest amplification factors for the central and western parts of Banda Aceh city ranged from 2.3 to 2.7. The lower amplification factors were found for the northern and southern areas of the city. The estimated ground motion intensity produced in Banda Aceh due to the Aceh segment scenario earthquakes are 8.4-9.3 MMI for magnitude $\mathrm{Mw} 7$ and 8.2-9.2 MMI for magnitude $\mathrm{Mw}$ 6.5. The high intensity located in the southwest of Banda Aceh city is near to the source of the earthquake, as shown in Fig. 7c, d. The earthquake intensities estimated for the Seulimeum segment scenario earthquake of magnitude $\mathrm{Mw}$ 7 are in the range of 7.6 to $8.6 \mathrm{MMI}$, with the high intensities occurring in eastern Banda Aceh, as shown in Fig. 7e.
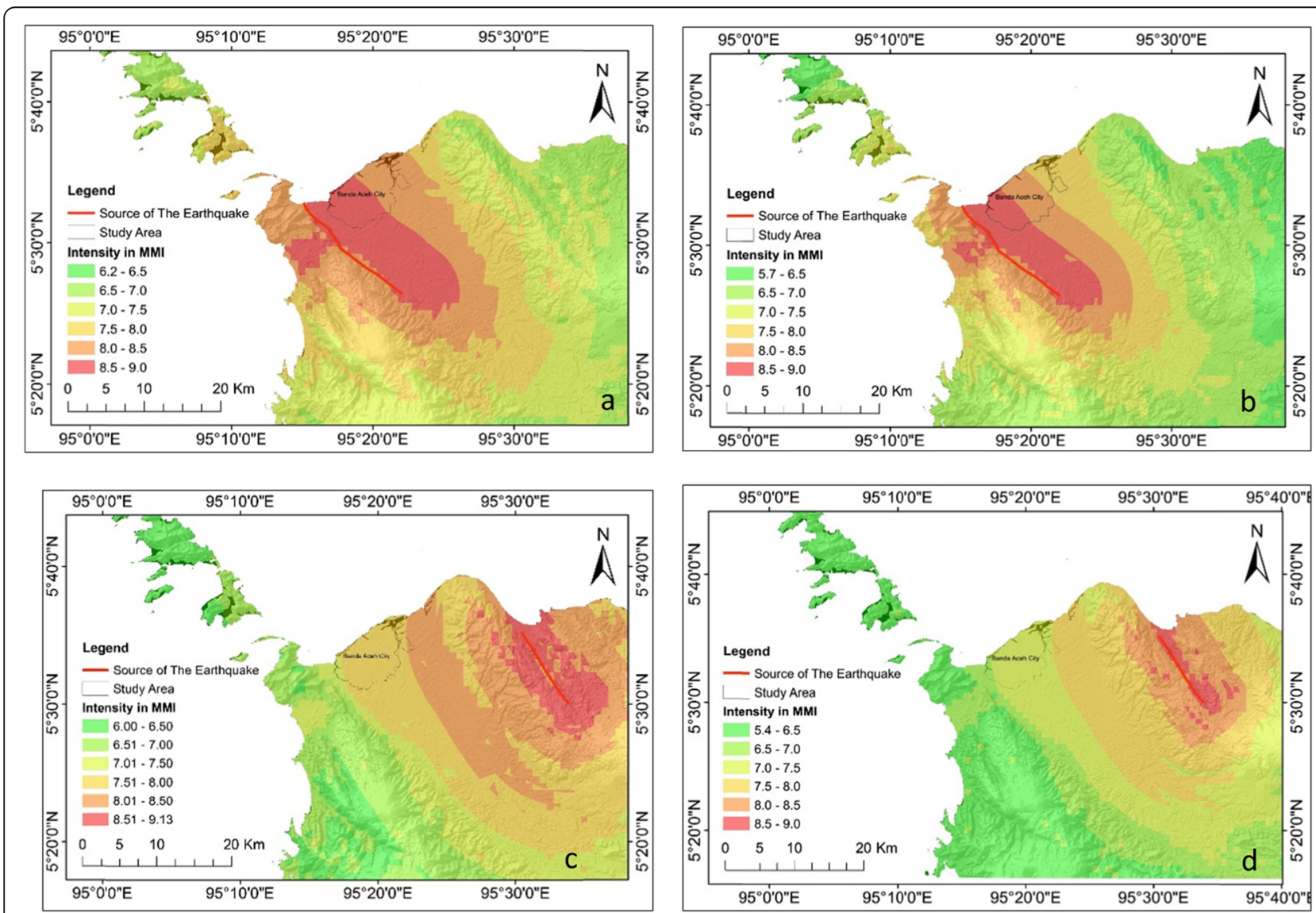

Fig. 6 Intensity map (MMI) from several earthquake scenarios; the site coefficient calculated from Global Vs30 (Allen and Wald 2009): a Intensity map of a Mw 7 from Aceh segment, b Mw 6.5 from Aceh segment, c Mw 7 from the Seulimeum segment, d Mw 6.5 from the Seulimeum segment. Digital elevation model dataset from NASA 2007 


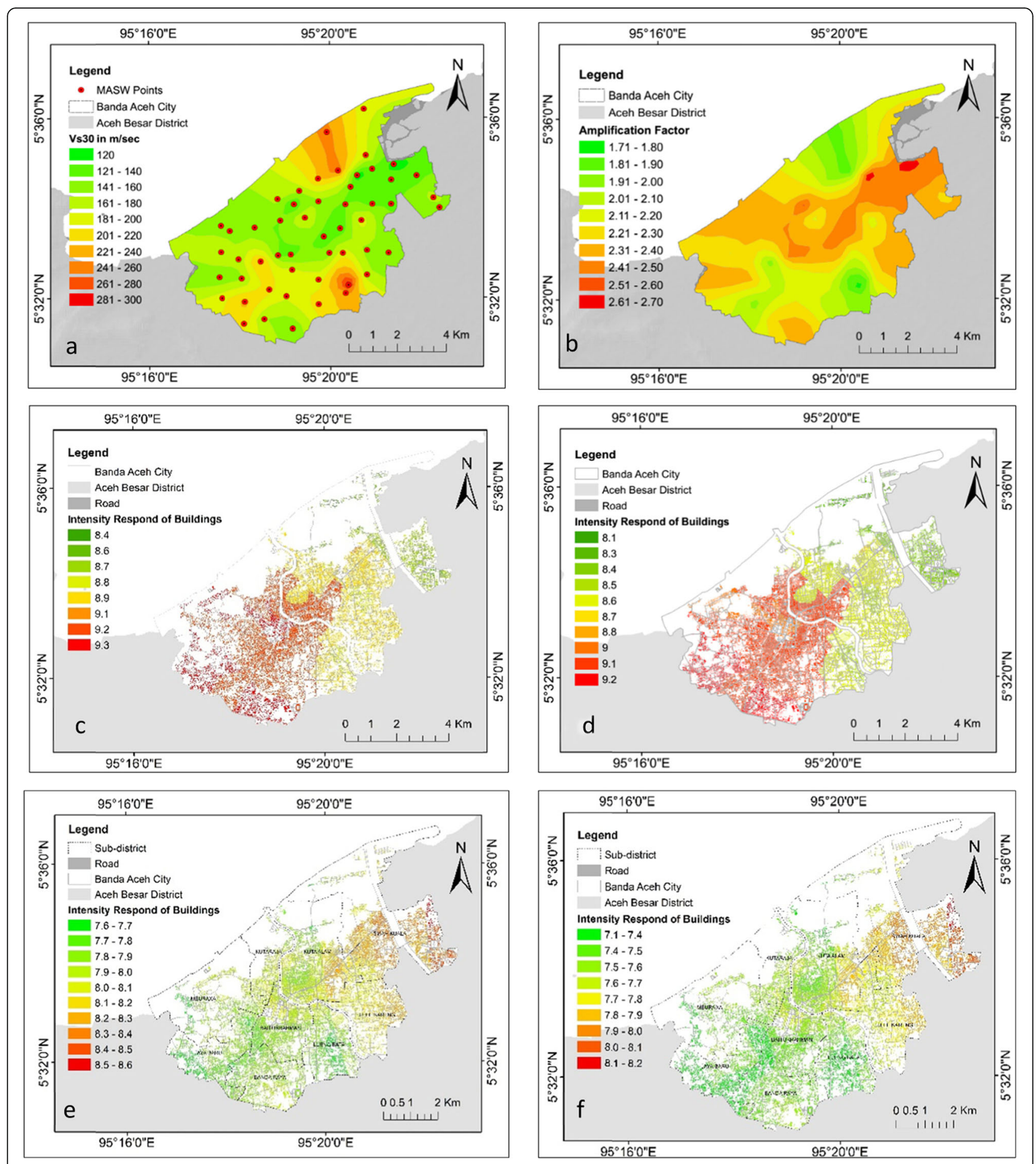

Fig. 7 Site coefficient map and intensity in Banda Aceh city. a Vs30 map around Banda Aceh city modified from Muzli et al. (2014) and Jamaluddin et al. (2018). b Amplification factor map and $\mathbf{c}$ Intensity map of Mw 7 magnitude earthquake from Aceh segment. $\mathbf{d}$ Mw 6.5 from the Aceh segment, e Mw 7 the Seulimeum segment, and $\mathbf{f}$ Mw 6.5 the Seulimeum segment

\section{Liquefaction effect}

The groundwater table level is one parameter that triggers the liquefaction (Chung and Rogers 2013). It influences the liquefaction effect by about $+/-20 \%$, compared to other parameters (Tonkin and Taylor Ltd 2013). Figure 8a shows the depth groundwater table in Banda Aceh city. These data are based on 20 locations of 1D Geo-electrical measurement. The map shows the interpolated data 

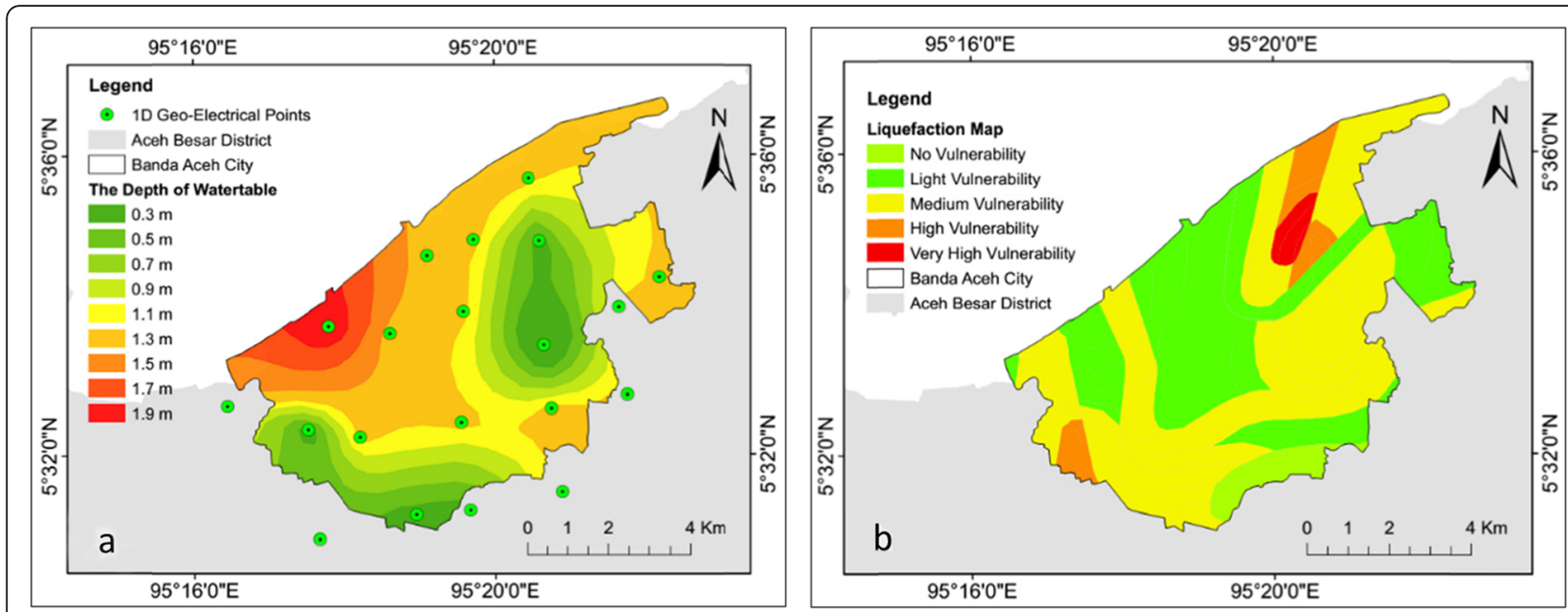

Fig. 8 a Water table level Map of Banda Aceh City, and $\mathbf{b}$ calculated liquefaction map of Banda Aceh developed by combining the liquefaction vulnerability map and groundwater table map

among the sites. The calculated liquefaction map of Banda Aceh based on the groundwater table and vulnerability liquefaction map is shown in Fig. 8b.

This study considered additional building damage caused by liquefaction, depending on the level of liquefaction vulnerability indicated in Fig. 8b. Liquefaction is assumed to result in $2.5,5,7.5$ and $10 \%$ additional damage to buildings in light, medium, high, and very high vulnerability zones, respectively.

\section{Damage distribution in several earthquake models}

In this study we generated four earthquake scenarios, two produced by the Aceh segment (Mw 7 and Mw 6.5) and two by the Seulimeum segment. Using GIS analysis, the earthquake intensity maps (Fig. 7c, d, e, and f) are clipped by the building polygon data (Fig. 4a). Building damage associated with various types of buildings was calculated using the fragility curve shown in Fig. 4b. This study calculated the damage ratios for each type of building in Banda Aceh city due to earthquake intensity and up to $10 \%$ additional damage cause by liquefaction. The results of the distribution of the building damage for each earthquake scenario are shown in Fig. 9.

\section{Human injury estimation}

As part of the injury estimation analysis, population size, damage ratio, and intensity had to be precisely determined. This study attempted to build the intensity map, the building population sizes, and the damage ratio as precisely as possible. The injury estimations in different earthquake scenarios were examined at two times during the day (2 PM and 2 AM), even though FEMA (2010) has suggested the use of three times per day (2 PM, 5 $\mathrm{PM}$ and $2 \mathrm{AM}$ ). This study considered two times per day because we assumed that people have similar patterns of activity at $2 \mathrm{PM}$ and $5 \mathrm{PM}$.

\section{Injury prediction during the day-time (2 PM)}

The time of occurrence at $2 \mathrm{PM}$ is a busy time when many people in Banda Aceh city are away from their homes and working in their offices. In a daytime event, the occupancy ratio used was 1 for offices, 0.3 for houses, and 0.5 for dormitories and hotels. Prediction of the number of injuries to people was calculated using Eq. (5) and the percentage of the population.

Figure 10 denotes the distribution of injury numbers around Banda Aceh city for several earthquake scenarios in percentages. This scenario considers that the people of Banda Aceh have no quick response plan or adequate access to evacuation. The scenario I in Fig. 10a is the worst-case scenario associated with an earthquake produced by the Aceh segment for Banda Aceh city. This scenario will injure $3.5-20 \%$ of the population buildings in almost all sub-districts. Scenario II also will harm $3.5-20 \%$ of the population in buildings. Scenario III is the worst-case scenario for an earthquake event from the Seulimeum segment of magnitude $\mathrm{Mw}$ 7. This earthquake will injure $2.3-15 \%$ of population in buildings. The IV scenario, with Mw 6.5 will injure $2-15 \%$ of the population in buildings.

\section{Injury prediction at night-time ( $2 A M)$}

In a night-time earthquake, all the residents of Banda Aceh city are assumed to be in their houses, and the offices have zero occupation. In this scenario, this study could compute the number of injuries based on the population data of residences as shown in Table 2. The predicted population was in turn calculated with GIS 

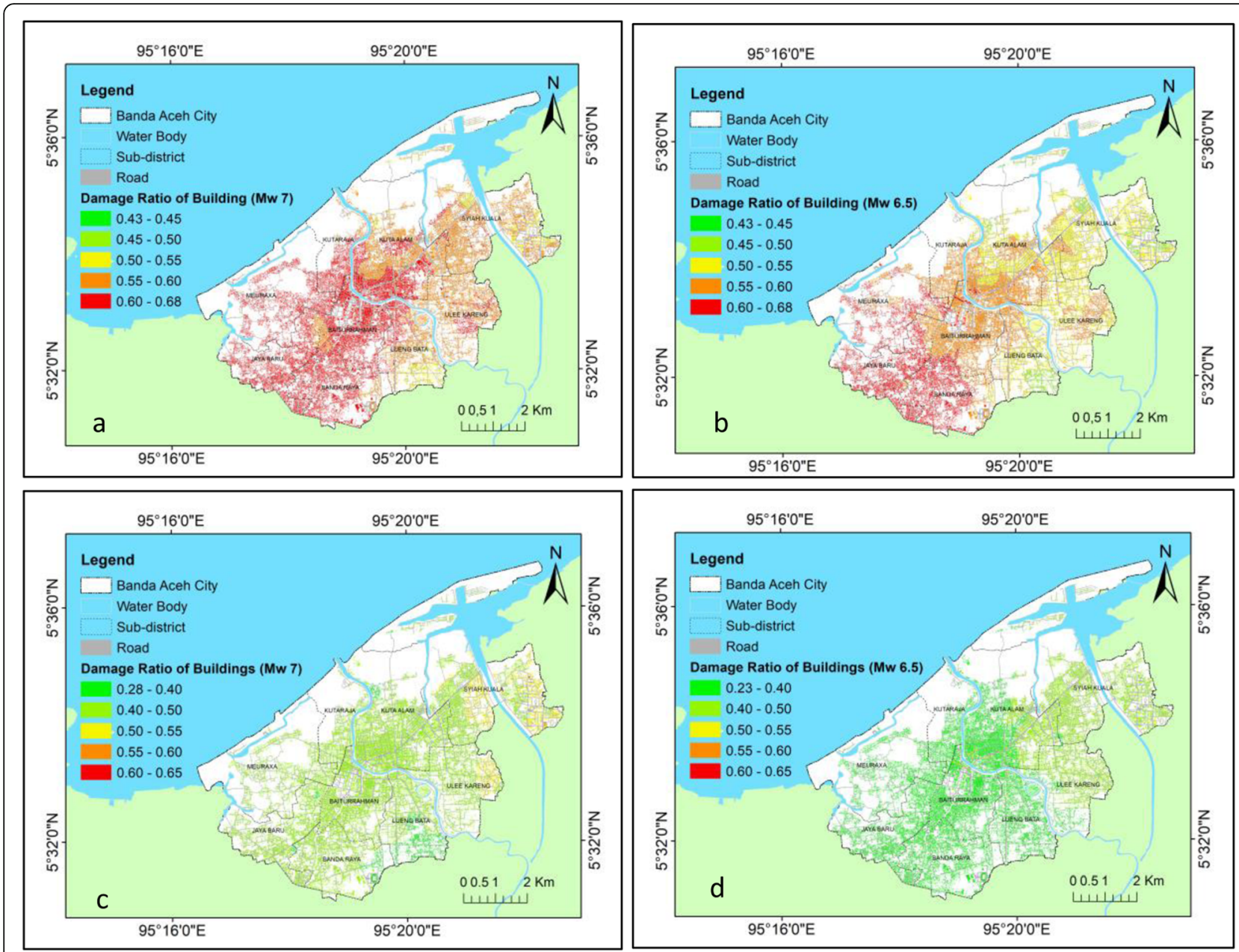

Fig. 9 Damage distribution for earthquake scenarios: a Mw 7 event on Aceh segment, b Mw 6.5 event on Aceh segment, c Mw 7 event on Seulimeum segment, d Mw 6.5 event on Seulimeum segment

analysis using population data from each village, the total area of the houses in the village and the area of each building, as determined in Eq. (4). The occupancy ratio at this time is 1.0 for all homes and residences, and 0 for offices, schools, and shops. The potential number of injured people in Banda Aceh city during a night-time event is shown in Fig. 11.

In a worst-case scenario for an earthquake on the Aceh segment, the number of injured will range from 1 to 2 people in each building. There was little difference in the number injured among scenarios I, II, III, and IV. In the total, approximately 20,264 people, or $7.8 \%$ of the population of 261,034 of Banda Aceh, would be injured in scenario I. The most casualties would be in the subdistricts of Kuta Alam (3032 casualties), Baiturrahman (2455 casualties), and Syiah Kuala (2427 casualties).

Scenario III is the worst-case earthquake from the Seulimeum segment. This segment is located in the eastern part of Banda Aceh, opposite to the Aceh segment. This event will injure 1-4 people in each building. The total number injured in this event would be approximately 14, 857 or $5.7 \%$ of Banda Aceh residents. The greatest numbers of casualties are in the sub-districts of Kuta Alam (2282 injuries), Syiah Kuala (2081 injuries), and Baiturrahman (1819 injuries). The detailed injury numbers for each district is shown in Table 6.

\section{Economic loss estimation}

The analysis of the damage distribution from the highest magnitude earthquake scenarios associated with the Aceh and Seulimeum segments are provided in Fig. 9. Figure 12 shows that the most affected districts in term of economic loss are sequentially Kuta Alam, Syiah Kuala, and Baiturrahman for the Mw 7 Aceh segment and Seulimeum segment scenarios. Generally, the Aceh segment scenario is predicted to have higher damage and associated cost than the Seulimeum segment. This is because Kuta alam district, the most populated district 

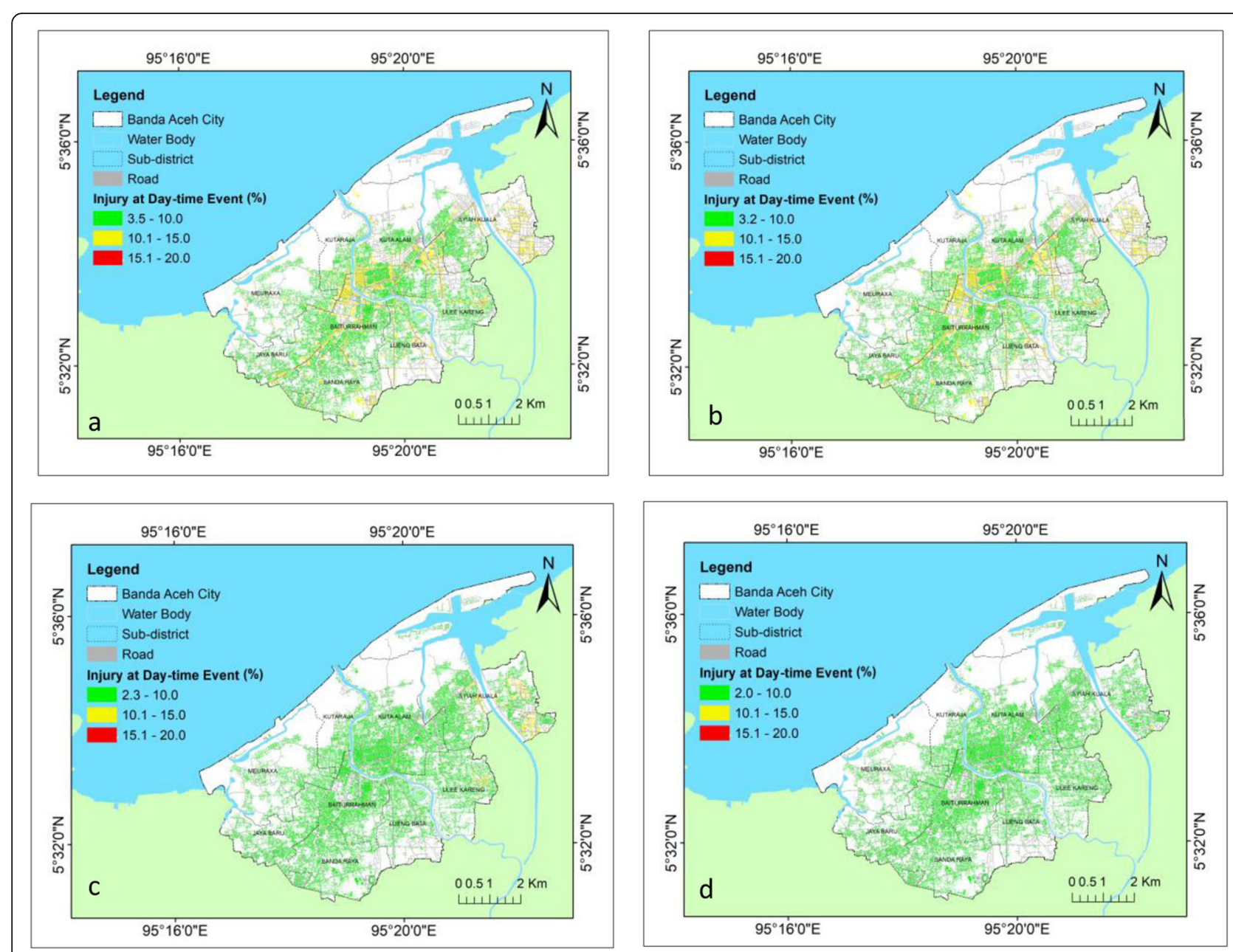

Fig. 10 Injury percentages distribution for the daytime scenario of an earthquake. a Intensity map of Mw 7 from Aceh segment, b Mw 6.5 from Aceh segment, c Mw 7 from Seulimeum segment, and $\mathbf{d}$ Mw 6.5 from the Seulimeum segment

in Banda Aceh city with many government offices, is closer to the Aceh compared to the Seulimeum segment. In total, economic loss in Banda Aceh would be 46,554, 706 million IDR or 3320 million USD if the Mw 7 earthquake occur on the Aceh segment and 34,710,843 million IDR or 2475 million USD if it occurred on the Seulimeum segment. More detail of economic loss estimation for each district can be seen in Fig. 12.

\section{Conclusions}

This study successfully developed several earthquake scenarios and determined the worst case scenario affecting the residents of Banda Aceh during daytime and nighttime earthquake events. The earthquake scenario ground motions in MMI were developed using globally applicable, macroseismic IPEs designed by Allen et al. (2012). Because these IPEs were developed for shallow crustal earthquakes, they suit the context of Banda Aceh situated along the Great Sumatran Fault (GSF). Two segments, i.e. the Aceh and the Seulimeum segments which are part of the GSF, are characterized as shallow crustal earthquake sources that have potential to generate severe impacts once major earthquake occurs. This study estimated the human casualties potentially caused in Banda Aceh by earthquakes generated from these segments.

The intensity validation model used with respect to Aceh province, along with the effects of local geology, work well to correctly estimate an intensity model. The fragility curve of C1-L developed by Tingatinga et al. (2013) and Naguit et al. (2017) are compatible with parameters found in Aceh province.

Various types of buildings and ground shaking will give rise to different damage ratios. In the worst scenario from the Aceh segment, 20,264 residents of Banda Aceh will be injured, which are about $7.8 \%$ of the total population of the city. The worst-case scenario associated with the Seulimeum segment would injure 14,857 people. Both of the scenarios were assumed to occur at $2 \mathrm{AM}$, 


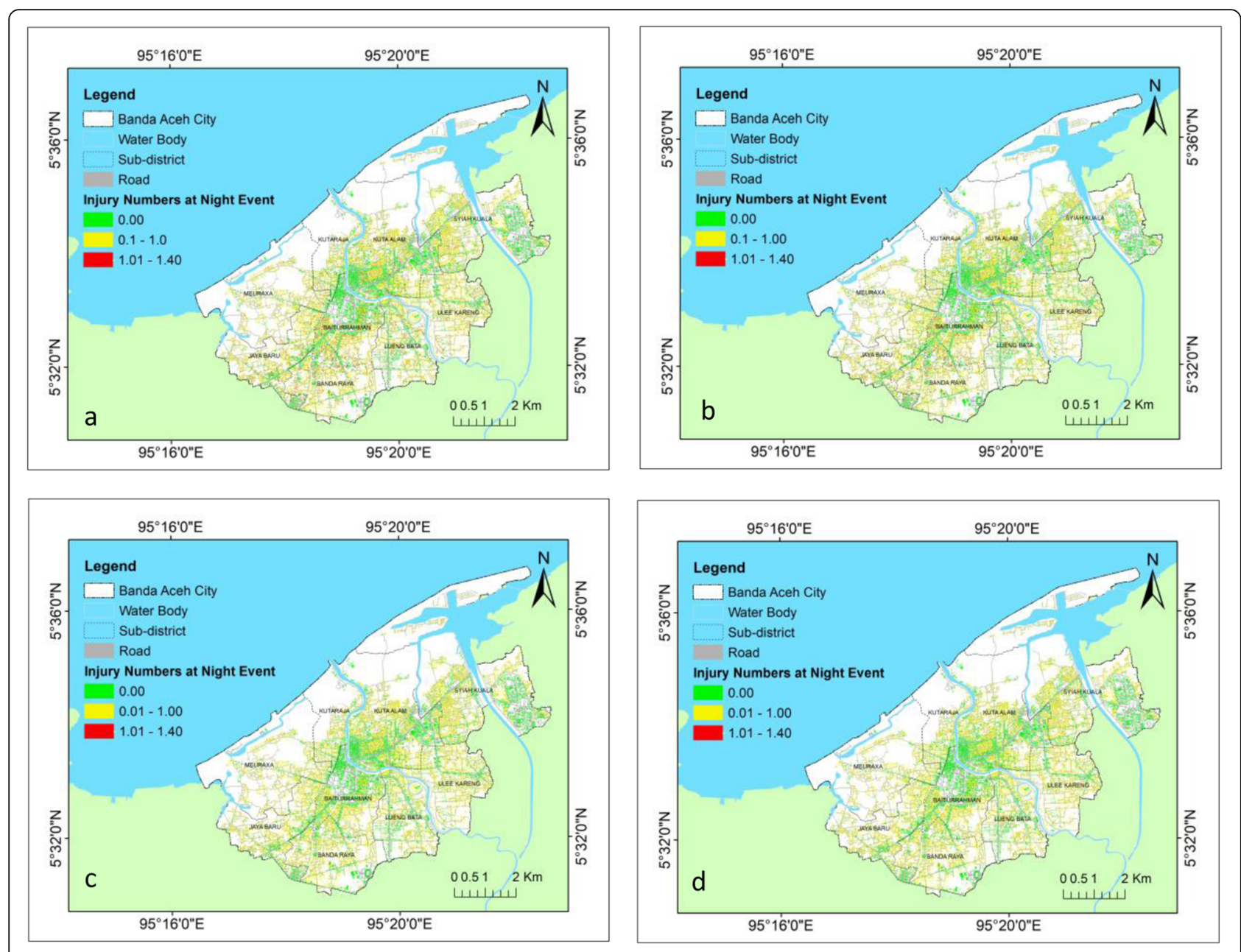

Fig. 11 Injury numbers distribution for the night-time scenario of an earthquake. a Intensity map of Mw 7 from Aceh segment, b Mw 6.5 from Aceh segment, c Mw 7 from Seulimeum segment, d Mw 6.5 from the Seulimeum segment

Table 6 The number of Injuries each Sub-district in Banda Aceh city

\begin{tabular}{llll}
\hline No & Sub-district & Injury number in worst case scenarios & \\
\cline { 3 - 4 } & & Mw 7 Aceh segment & Mw 7 Seulimeum segment \\
\hline 1 & Kuta Alam & 3032 & 2282 \\
2 & Baiturrahman & 2455 & 1699 \\
3 & Syiah Kuala & 2427 & 2081 \\
4 & Jaya Baru & 2389 & 1589 \\
5 & Banda Raya & 2248 & 1532 \\
6 & Ulee Kareng & 2245 & 1819 \\
7 & Meuraksa & 2256 & 1547 \\
8 & Lueng Bata & 1982 & 1426 \\
9 & Kuta Raja & 1231 & 882 \\
\hline
\end{tabular}




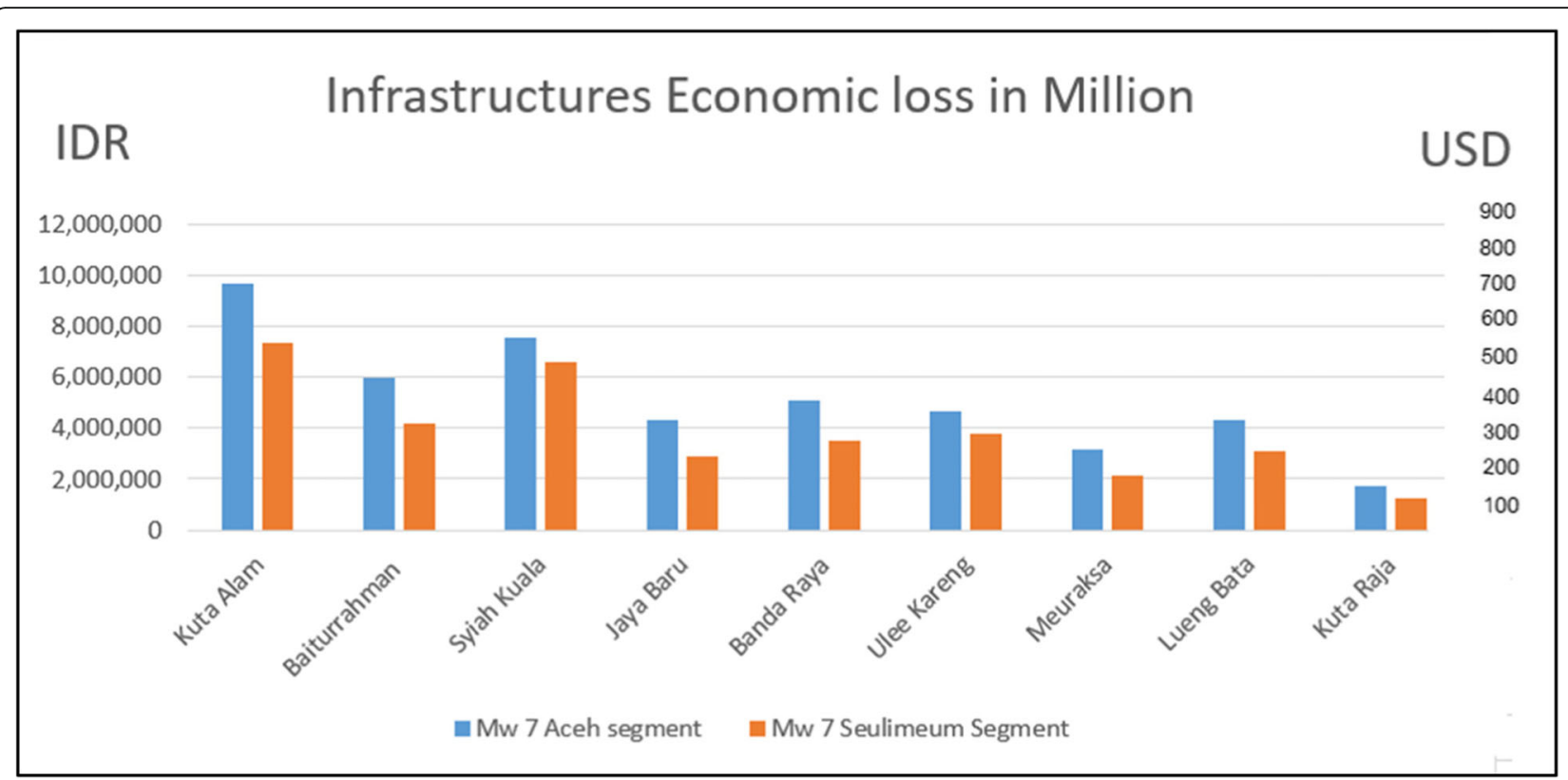

Fig. 12 The infrastructures economic loss each districts in Banda Aceh city due to Mw 7 earthquake from Aceh segment and Seulimeum segment

when most people are at home. As explained earlier, the quality control on private and non-government building construction in Indonesia is weak, this could also contribute to the large number of potential human casualties due to the earthquakes. The emergency situation potentially generated by such an earthquake could put disaster emergency response agencies under huge pressure. We suggest the Disaster Management Agency of the city to increase their capacity in order to give punctual and effective measures to respond to such emergency situations. Implementation of building codes and quality control on private and non-government buildings should be imposed.

\section{Abbreviations}

1D: One dimension; AM: Ante Meridiem; C1-L: Low-Rise Concrete Moment Frame; C1-M: Medium Rise Concrete Moment Frame; FEMA: Federal Emergency Management Agency; GIS: Geographic information system; GSF: Great Sumatra fault; IDR: Indonesia Rupiah; IPEs: Intensity prediction equations; M: Magnitude; MASW: Multichannel analysis of the surface waves; MMI: Modified Mercalli Intensity; Mw: Moment magnitude; NASA: National Aeronautics and Space Administration; PM: Post Meridiem; SRTM: Shuttle radar topography mission; USD: United States Dollar; USGS: United States Geological Survey; Vs30: Shear wave velocity in average 30 m; W1-L: Low-Rise Light Wood Frame

\section{Acknowledgements}

The authors are highly thankful to the Department of Population and Civil Registration of Banda Aceh City (Dinas Kependudukan dan Pencatatan Sipil Kota Banda Aceh) for providing population data of Banda Aceh city, Indonesia.

\section{Authors' contributions}

$I R$, as data analysis and manuscript preparation on earthquake damage analysis. $\mathrm{Yl}$ and $\mathrm{S}$, as analyse on the type of buildings in the regions, $\mathrm{M}$, as GIS data processing and analyses. UM and PC, support on the interpretation of the results. MNA, conduct a data acquisition on type of buildings in study area. All authors read and approved the final manuscript.

\section{Funding}

This study would not be possible without supporting funding from START International Inc., USA in PARR Fellowship Program 2017. Publication of this paper was made based on World Class Professor Program-Scheme A received by TDMRC of Syiah Kuala University from Ministry of Research, Technology, and Higher Education (RISTEKDIKTI) of Indonesia in 2018.

\section{Availability of data and materials}

The datasets used and/or analyzed during the current study are available from the corresponding author on reasonable request.

\section{Competing interests}

The authors declare that they have no competing interests.

\section{Author details}

${ }^{1}$ Department of Geological Engineering, Faculty of Engineering, Syiah Kuala University, Banda Aceh, Indonesia. ${ }^{2}$ Tsunami and Disaster Mitigation Research Center (TDMRC), Syiah Kuala University, Banda Aceh, Indonesia. ${ }^{3}$ Department of Civil Engineering, Faculty of Engineering, Syiah Kuala University, Banda Aceh, Indonesia. ${ }^{4}$ Department of Mining Engineering, Faculty of Engineering, Syiah Kuala University, Banda Aceh, Indonesia. ${ }^{5}$ Department of Physic, Faculty of Sciences, Syiah Kuala University, Banda Aceh, Indonesia. ${ }^{6}$ Research School of Earth Science, College of Science, The Australian National University, Canberra, Australia.

Received: 17 October 2019 Accepted: 27 January 2020

Published online: 05 February 2020

\section{References}

Allen TI, Wald DJ (2009) On the use of high-resolution topographic data as a proxy for seismic site conditions (Vs30). Bull Seismol Soc Am 99(2A):935-943

Allen TI, Wald DJ, Worden CB (2012) Intensity attenuation for active crustal regions. J Seismol 16:409-433

Baiocchi V, Dominici D, Ferlito R, Giannone F, Guarascio M, Zucconi M (2012) Test of a building vulnerability model for L'Aquila earthquake. Appl Geomatics 4(2):95-103. https://doi.org/10.1007/s12518-014-0142-z 
Barber AJ, Crow MJ (2005) Pre-Tertiary stratigraphy. In: Barber AJ, Crow MJ, Milson JS (eds) Sumatra: geology, resources, and tectonic evolution. Geological Society, London, p 40

Bennet JD, Bridge DM, Cameron DR, Djunuddin A, Ghazali SA, Jeffrery DH et al (1981) Geologic 1:250,000 map of Banda Aceh Quadrangle, Sumatra. Geological Research and Development Centar (GRDC), Bandung

Borcherdt RD (1997) Spatial ground motion amplification analysis. In: Frost D (ed) Proceedings of Geo-Logan'97, pp 56-69

Borcherdt RD, Eeri M (1994) Estimation of site-dependent response spectra for design (methodology and justification). Earthquake Spectra 10(4):617-653

Chlieh M, Avouac JP, Sieh K, Natawidjaja DH, Galetzka J (2008) Heterogeneous coupling of the Sumatran megathrust constrainedby geodetic and paleogeodetic measurements. J Geophys Res 113:B05305

Chung J-W, Rogers JD (2013) Influence of assumed groundwater depth on mapping liquefaction potential. Environ Eng Geosci 19(4):377-389. https:// doi.org/10.2113/gseegeosci.19.4.377

Cinicioglu SF, Bozbey I, Oztoprak S, Kelesoglu MK (2007) An integrated earthquake damage assessment methodology and its application for two districts in Istanbul, Turkey. Eng Geol 94:145-165

Coburn A, Spence R (2002) Earthquake protection, 2nd edn. Wiley, West Sussex

Culshaw MG, Duncan SV, Sutarto NR (1979) Engineering geological mapping of the banda aceh alluvial basin, northern sumatra, Indonesia. Bull Int Assoc Eng Geol 19:40-47

Daryono MR, Tohari A (2016) Surface rupture and geotechnical features of the July 2, 2013 tanah gayo earthquake. Indones J Geoscience 3(2):95-105

FEMA (2010) Multi-hazard loss estimation methodology, earthquake model (HAZUS-MH), Federal Emergency Management Agency. Department of Homeland Security Emergency Preparedness and Response Directorate, Washington, D.C

Gentile R, Galasso C, Idris Y, Rusydy I, Meilianda E (2019) From rapid visual survey to multi-hazard risk prioritisation and numerical fragility of school buildings. Nat Hazards Earth Syst Sci 19:1365-1386. https://doi.org/10.5194/nhess-191365-2019

Guettiche A, Gue'guen P, Mimoune M (2017) Economic and human loss empirical models for earthquakes in the mediterranean region, with particular focus on Algeria. Int J Disaster Risk Sci 8:415-434. https://doi.org/ 10.1007/s13753-017-0153-6

Hashemi M, Alesheikh AA (2011) A GIS-based earthquake damage assessment and settlement methodology. Soil Dyn Earthq Eng 31:1607-1617

Holzer TL, Noce TE, Bennett MJ (2011) Liquefaction probability curves for surficial geologic deposits. Environ Eng Geosci 17:1-21

Idris Y, Cummins P, Rusydy I, Muksin U, Syamsidik S, Habibie MY, Meilianda E (2019) Post-earthquake damage assessment after the $6.5 \mathrm{mw}$ earthquake on December, 7th 2016 in Pidie Jaya, Indonesia. J Earthq Eng:1-18. https://doi. org/10.1080/13632469.2019.1689868

Ito T, Gunawan E, Kimata F, Tabei T, Simons M, Meilano I et al (2012) It isolating along-strike variations in the depth extent of shallow creep and fault locking on the northern Great Sumatran Fault. J Geophys Res 117:1-16

Jaiswal KS, Wald DJ (2013) Estimating economic losses from earthquakes using an empirical approach. Earthquake Spectra, 29 (1):309-324. https://doi.org/10. $1193 / 1.4000104$

Jamaluddin K, lqbal F, Rusydy I, Chairullah B (2018) Analisis vs30 lokasi kecamatan syiah kuala dalam upaya mitigasi bencana gempa bumi kota Banda Aceh. Jurnal Teknik Sipil 7(2):75-80 (in Indonesian)

Karimzadeh S, Feizizadeh B, Matsuoka M (2017) From a GIS-based hybrid site condition map to an earthquake damage assessment in Iran: Methods and trends. Int J Disaster Risk Reduction 22:23-36

Karimzadeh S, Miyajima M, Hassanzadeh R, Amiraslanzadeh R, Kamel B (2014) A GIS-based seismic hazard, building vulnerability and human loss assessment for the earthquake scenario in Tabriz. Soil Dyn Earthq Eng 66:263-280

Liu Y, Li Z, Wei B, Li X, Fu B (2019) Seismic vulnerability assessment at urban scale using data mining and GIScience technology: application to Urumqi (China). Geomatics, Nat Hazards Risk 10(1):958-985

McCaffrey R (2009) The tectonic framework of the Sumatran subduction zone. Annu Rev Earth Planet Sci (37):345-366. https://doi.org/10.1146/annurev. earth.031208.100212

Miura H, Midorikawa S, Fujimoto K, Pacheco BM, Yamanaka H (2008) Earthquake damage estimation in Metro Manila, Philippines based on seismic performance of buildings evaluated by local experts' judgments. Soil Dyn Earthq Eng 28:764-777
Muksin U, Rusydy I, Erbas K, Ismail N (2018) Investigation of Aceh segment and Seulimeum fault by using seismological data; a preliminary result. J Phys 1011:012031 IOP Publishing

Muzli M, Rudyanto A, Sakti AP, Rahmatullah FS, Dewi KR, Santoso E, Muhajirin, Pramono S, Mahesworo RP, Jihad A, Ardiyansyah T, Satria LA, Akbar RN, Madijono R (2014) Studi klasifikasi tanah permukaan untuk wilayah banda aceh. Proceeding of Science Aplication on Disaster Risk Reduction, Banda Aceh, pp 159-167 (in Indonesian language)

Naguit M, Cummins P, Edwards M, Ghasemi H, Bautista B, Ryu H, Haynes M (2017) From source to building fragility: post-event assessment of the 2013 M7.1 Bohol, Philippines, Earthquake. Earthquake Spectra 33(3):999-1027

Okada S, Takai N (2000) Classifications of structural types and damage patterns of buildings for earthquake field investigation. In: 12th World Conference on Earthquake Engineering (paper 0705), Auckland

Rusydy, I., Faustino-Eslava, D. V., Muksin, U., Gallardo-Zafra, R., Aguirre, J. C., Bantayan, N. C., ... Dakey, S. (2017a). Building vulnerability and human loss assessment in different earthquake intensity and time: a case study of the University of the Philippines, Los Baños (UPLB) Campus. IOP Conf Ser Earth Environ Sci. 56, p. 012006. Banda Aceh: IOP Publishing. doi:https://doi.org/10. 1088/1755-1315/56/1/012006

Rusydy I, Faustino-Eslava DV, Muksin U, Gallardo-Zafra R, Aguirre JJ, Bantayan NC et al (2018a) GIS-based earthquake damage prediction in different earthquake models: a case study at the university of the Philippines Los Baños, Philippines. Philipp J Sci 147(2):301-316

Rusydy I, Jamaluddin K, Fatimah E, Syafrizal S, Andika F, Furumoto Y (2017b) Estimation of site amplifications from shear-wave velocity at pyroclastic deposits and basins in Aceh Tengah and Bener Meriah district, Aceh province, Indonesia. Int J Disaster Manag 1(1):46-54

Rusydy I, Muksin U, Mulkal M, Idris Y, Akram MN, Syamsidik S (2018b) The prediction of building damages and casualties in the Kuta Alam sub districtBanda Aceh caused by different earthquake models. AIP Conference Proceedings, Bandung. https://doi.org/10.1063/1.5047297

Rusydy I, Syamsidik, Pagihariyadi P (2015) Pemetaan makroseismik untuk pendugaan sumber gempa bumi, studi kasus: gempa bumi Aceh Tengah 2 Juli 2013. Konferensi Nasional FPT PRB. LPPKM, Universitas Sebelas Maret, Surakarta, pp 15-20 (in Indonesia language)

Saputra A, Rahardianto T, Revindo MD, Delikostidis I, Hadmoko DS, Sartohadi J, Gomez C (2017) Seismic vulnerability assessment of residential buildings using logistic regression and geographic information system (GIS) in Pleret Sub District (Yogyakarta, Indonesia). Geoenvironmental Disasters 4(11):1-33. https://doi.org/10.1186/s40677-017-0075-z

Sieh K, Natawidjaja D (2000) Neotectonics of the Sumatran fault. J Geophys Res 105(B12):28,295-28,326

Sun B, Chen H, Zhong Y (2012) Development of earthquake disaster loss estimation in China. 15 WCEE, Lisboa Retrieved from https://www.iitk.ac.in/ nicee/wcee/article/WCEE2012_3599.pdf

Tim Revisi Peta Gempa Indonesia (2010) Ringkasan hasil studi tim revisi peta gempa Indonesia 2010. BNPB, AIFDR, RISTEK, DPU, ITB, BMKG, LIPI, ESDM, Jakarta (in Indonesian language)

Tingatinga E, Pacheco B, Hernandez J Jr, Ignacio U, Germar F, Longalong R et al (2013) Development of heuristic seismic vulnerability curves of key building types in the Philippines. In: 10cuee Conference Proceedings. Tokyo Institute of Technology, Tokyo Retrieved from Global Earthquake Model (GEM) Workshop-Nanyang Technological University, Singapore

Tohari A, Sugianti K, Syahbana AJ, Soebowo E (2015) Cone penetration test (CPT)-based liquefaction susceptibility of Banda Aceh City. Jurnal RISET Geologi dan Pertambangan 25(2):99-110. https://doi.org/10.14203/ risetgeotam2015.v25.204

Tonkin and Taylor Ltd (2013) Liquefaction vulnerability study. Earthquake Commission, Wellington Retrieved July 31, 2017, from https://www.eqc.govt. nz/sites/public_files/documents/liquefaction-vulnerability-study-final.pdf

Wood RM, Steedman RS (1992) Earthquake induced groundwater change and liquefaction. Earthquake Engineering Tenth World Conference, Rotterdam

\section{Publisher's Note}

Springer Nature remains neutral with regard to jurisdictional claims in published maps and institutional affiliations. 